International

Medical Society

http://imedicalsociety.org

\title{
Parents' Perception
}

\section{about Autistic Children: a Descriptive Study

Maria Irisanny Kalliny Coelho Monte ${ }^{1}$, Wanderson Alves Martins ${ }^{1}$, Jackeline Bezerra Torres ${ }^{1}$, Leonardo Alexandrino Da Silva², Marcela Ariadne Braga Gomes Tomé3, Maria Isabelly Fernandes Da Costa ${ }^{3}$, Francisca Andrea Marques de Albuquerque ${ }^{4}$, Mirna Albuquerque Frota ${ }^{5}$, Fabiane Do Amaral Gubert ${ }^{6}$, Marilia Braga Marques ${ }^{6}$, Janaina Fonseca Victor Coutinho ${ }^{6}$, Mariana Cavalcante Martins ${ }^{6}$, Paula Sacha Frota Nogueira ${ }^{6}$, Patricia Neyva Costa Pinheiro ${ }^{6}$, Eveline Pinheiro Beserra ${ }^{6}$, Viviane Mamede Vasconcelos ${ }^{7}$

\section{Abstract}

Introduction: The infantile autism is a developmental disorder that affects social interaction, language, cognition and quality of life.

Objective: Describing the parents' perception about daily care for autistic children.

Methods: It was a descriptive and qualitative study performed with parents of autistic children attending a reference health center in a Brazilian city. A semi-structured interview was used to collect data. The participants gave information about their socioeconomic status, daily care activities, hope and social interaction.

Results: Based on the speeches of the participants, the following categories were described: negative feelings about the disorder; the (in)dependent autistic children and future perspectives for them; family acceptance of autism, which required appropriated changes in the family environment.

Conclusion: Analyzing the parents' perception of autism is essential because it enables the multidisciplinary group of health professionals to establish adequate and specific health interventions.
1 Student of Nursing, Integrated Faculty of Grande Fortaleza, Fortaleza, Brazil.

2 Student of Nursing, Federal University of Ceará, Fortaleza, Brazil.

3 Nurse. Student of Nursing Undergraduate Program, Doctoral (or Master) level, Federal University of Ceará, Fortaleza, Brazil.

4 Nurse. Professor at the Graduate Nursing Course of Integrated Faculty of Grande Fortaleza, Fortaleza, Brazil.

5 Nurse. Ph.D. Professor at the Undergraduate and Graduate Nursing Course of University of Fortaleza, Fortaleza, Ceará, Brazil.

6 Nurse. Ph.D. Professor at the Undergraduate and Graduate Nursing Course of Federal University of Ceará, Fortaleza, Brazil.

7 Nurse. Ph.D. Professor at the Graduate Nursing Course of Integrated Faculty of Grande Fortaleza, Fortaleza, Brazil.

\section{Contact information:}

\section{Mariana Cavalcante Martins.}

Address: Rua Alexandre Barauna, 949, Rodolfo Teófilo, 60430-160, Fortaleza, Ceará.

Tel: (085) 33668457

\section{Keywords}

Quality of Life; Autistic Disorder.
ほ marianaenfermagem@hotmail.com 


\section{Introduction}

Autism is a developmental human disorder that has been studied for nearly six decades. Even though scientists have uncovered many aspects of the autism, it still has some indecipherable characteristics. The phenomenon of autism is usually noticed before three years of age, and is characterized by qualitative deviations and decreased communication, behavioral and social interaction abilities [1].

The infantile autism is a developmental disorder that affects social interaction, language and the cognitive process. The autistic spectrum causes a wide range of neurodevelopmental disorders, whose main axes cover three main areas: social interaction difficulties; verbal and non-verbal difficulties; restricted and repetitive patterns of behavior [2].

The incidence of autism has increased worldwide. To illustrate this epidemiologic transition, the autism incidence over the 80s and 90s in the United States was between 4 to 10 per 10,000 children. Current studies have pointed out the autism incidence was between 30 to 50 per 10,000 children [3], and 1 case per 68 children under 8 years old [4]. In Brazil, according to data gathered from epidemiologic studies performed between 2010 and 2011 in the Latin America, the Brazilian city of Atibaia had the prevalence of 1 case of autism per 368 children aged between 7 and 12 years [5].

Autism is basically diagnosed through the evaluation of clinical aspects based on direct observation of the child's behavior and interviews performed with parents or caregivers about the identification of abnormalities in the following developmental domains: reciprocal social interaction; communication; behavioral repertoire of narrow, repetitive and stereotyped preferences [6].

Those above domains can directly affect quality of life; therefore, it is necessary to evaluate the children's behavior and how autism is faced by their parents. The analysis of these domains can also help the creation of instruments with accurate clinical utility, whose interventions are more acceptable and cause positive impact on caregivers and on the care of autistic children [7].

The quality of life has been classified as a method to measure humans' life conditions. This method covers physical and mental well-being; psychological, emotional, social relationships, health, and educational domains. The analyses of these domains must respect how each person sees his own life status, which is based on cultural background and personal values [8].

Analyzing quality of life is not an easy task to perform, but it is extremely necessary. It is essential that professional workers know what parents of autistic children face every day since it impacts on their daily care activities, which are linked to the improvement of social and mother-son relationships.

The parents of autistic children's perceptions provide a better understanding of the capabilities of these children and improves the creation of specific health interventions that contributes to a better quality of life and well-being [9].

The authors emphasized that the care provided by parents or caregivers of autistic children is often impaired because they become dependent on their children. It means that parents and caregivers decide not putting their own needs first, compromising their social interaction and relationships with their partners [10].

Because of the global magnitude related to infantile autism, it was necessary to analyze the parents of autistic children's perception facing new life condition in order to better understand the reality of these children and to propose strategies that positively impact the lives of these children, their caregivers and families.

Based on the above arguments, the authors aimed to describe the parents' perception about daily care for autistic children.

\section{Methods}

It was a descriptive and qualitative study performed in Fortaleza, Ceara state, Brazil between February 
and April 2015 in a non-profit reference health center, which offers treatment for autistic children. The authors chose to analyze the perception of 15 parents because their children had communication and cognitive disorders. Inclusion criteria were determined as follows: being parents of children who had a confirmed medical diagnosis of autism; parents of autistic children aged between 4 and 12 years.

The number of the interviewed participants was based on data saturation, which is a conceptual approach frequently used in qualitative health studies [11].

Data collection was carried out after approval from a Brazilian Research Ethics Committee, under the number CAAE: 33209114.7.0000.5618. The procedures of this study were in accordance with the Brazilian resolution on the conduction of research with humans.

The process of data collection was performed in two steps: (1) a questionnaire was used to characterize parents and their autistic children (gender, age, and family income); (2) a semi-structured interview was composed by four open questions as follows: What does an autistic child mean for you?; How has this experience affected you and your family life?; How has the social interaction of your child affected his development?; "What expectations do you have for your child in the future?.

Data collection lasted 30 minutes for each interviewed parent. In order to afford privacy and information confidentiality, the interviews were performed in a reserved room, which had no noise interference and other people. The interviews were accurately recorded and then transcribed. The speeches gathered from the interviews were identified by the letter $\mathrm{R}$ (which stands for Responsible for the child) followed by a number that represents the chronology sequences of the interviews.

Data analysis was performed using the systematic method, which is divided into the following steps: (1) exploratory, (2) data collection, (3) data analysis and process [12]. Based on the analysis of the speeches, the following categories were found: negative feelings about the disorder; the (in)dependent autistic children and future perspectives for them; family acceptance of autism, which requires appropriated changes in the family environment.

\section{Results and Discussion}

Regarding the family members in charge of handling direct care for the autistic children, 74\% were mothers, and 26\% were fathers. Data about the autistic children revealed that $14 \%$ of them were younger than 9 years of age; $60 \%$ were adolescents aged between 11 and 19 years; 26\% were aged between 20 and 27 years. The majority of the participants were male (80\%), and only $20 \%$ were female. According to our data, $87 \%$ of the families received more than one Brazilian minimum wage and $13 \%$ received less than one Brazilian minimum wage.

Autism requires family changes that are necessary to them getting used to this new phase of life. Parents and relatives had to find new meanings for their lives and children. Moreover, they had to adapt their activities of daily living and rearrange their personal commitments and duties.

(...) God sent him to us, so we must accept him; but it's really complicated because of the prejudice and discrimination from other people, am I right?.

It's complicated... it's not easy.

(...) sadness, that is it. Although he lives in the hospital, it's all sadness. A friend of mine doesn't help me with school transportation.

I don't want to face it again. 
The manner in which parents and relatives interact with children directly influences the acceptance of a new family member. In addition to this characteristic, this family acceptance is noticed by analyzing their behavior, hopes, expectations, needs and limitations [13].

The family relationship has a crucial role for the commitment and care delivery that are required by children. This fact may cause negative impacts on the mental health of parents and relatives and decrease the quality of life of the ones who are in charge of taking care of autistic children [14].

Based on the above assumptions, it is possible to affirm that families have excessive work to care for autistic children. Consequently, this fact may lead to the onset of negative feelings and uncertainty regarding the autistic children. These evidences were identified in the following speeches:

(...) I have no expectation to see her getting any better... only God knows... it is very hard... there are different types of autism, am I right? As you can see, autistic children are different. Some of them are able to speak, but mine isn't. My child only injures himself, not others."

No improvements... that is it... he isn't getting any better.

The birth of a child with disability may alter parents' dreams and expectations, especially when a healthy child was idealized by them. The frustration caused by not having a healthy child triggers anxiety in parents, which is responsible for them facing a mourning period. Moreover, having an autistic child is often linked to financial and emotional difficulties [15].

The authors claimed out that family instability may cause isolation, which requires special care for those who are facing it [16].
It was noticed that parents had a notable level of resistance to accept the children's conditions. This fact may be linked to the required changes in their lives that can be responsible for a certain isolation level in parents, relatives and caregivers, which leads to mental health impairment.

Regarding the improvement of being independent, autistic children must be exposed to social contact and activities of daily living, such as: putting shoes on, organizing toys, and setting tables before meals. Although these exercises seem very simple, they are very powerful to increase these children's development and social abilities [17].

I want him to be independent in the future. I mean getting married, having his own family... you know! I don't want him being dependent on me... I want a normal life for him!

The best ones, am I right? I do everything for him to be as independent as possible. Despite his limitations, I want him being able to take a shower, eat... performing basic life activities... can you see what I mean?

Most of the parents affirmed their major expectative was to see their child being as independent as possible and able to perform basic activities of daily living, such as personal hygiene, self-care and leisure. These basic activities of daily living are often a challenge for autistic children because they have problems with spatial awareness [18].

As an approach to improve the health condition of autistic children, the parents pointed out that social interaction with children of the same age promotes the sharing of ideas and roles. Moreover, it facilitates the performance of activities that require discussion and interpersonal abilities to solve conflicts. 
The social contact with other children has helped him a lot... during the social contact with other children, he got better in body language and socialization... and he has been able to better express his thoughts... It has improved so much our lives.

She is able to communicate very well... she really likes to ask questions about everything. She interacts so much... if she were here, she would ask you many questions... she talks a lot.

The quality of life of autistic children can provide a better understanding, possibilities and planning necessary for the creation of interventions, which aim to be very specific for this population. The implementation of these specific interventions positively impacts the autistic children's development and improves their environmental adaptation and the development of a better quality of life and wellbeing [14].

Parents of autistic children should often reevaluate their plans and expectations related to their child and family in order to provide a better quality of life, especially for the child. Through the analysis of the speech of the participants, it was possible to identify different feelings connected to future expectations for their children, for example:

How could he work? He is only going to socialize, but he will never work.

I don't have any expectation for him... I've set goals and one of them is to raise a child that is going to be as independent as possible... longterm improvements require patience, money, time... so, it's my goal: my son becoming as independent as possible.
Although autistic children have delays on the development of some expected abilities, it is possible to notice a gradual and progressive improvement in their independence abilities as they grow [18].

If the family does not pay attention to the development of their children, there will probably have an increase in the challenge situations without treatment, and it will cause a negative impact on the child. The parents' love is a powerful element necessary for the teaching-learning process because it will be identified in the school and by the society [19].

The authors identified that the care delivered to autistic children focuses on the development of the abilities of daily living, such as social interaction, in order to improve the independence level of the children. Therefore, parents, relatives and caregivers must be engaged in the creation of specific interventions designed for autistic children.

Different reactions are reported when a child is diagnosed with autism. The acceptance process of autism includes grief, denial, depression, guilt, shame, anger, acceptance and adaptation.

In consonance with the above assumptions, parents of autistic children often face a psychological suffering stage, which is characterized by the nonacceptance of their child's disability [17]. However, it is an adaptation process that is later overcome by the family, as follows below:

In the beginning, it was a misfortune... I am being honest with you... but today I don't think like this anymore because I got used to it.

A learning process, I think it is.

Families are a complex network of relationships, emotions, feelings and behaviors. The discovery of a disorder in some family member has major repercussions, especially when the children get the diagnosis. Consequently, families have to face important 
changes because new roles and responsibilities are established [20].

Well, it is not easy to raise a child with autism, do you know what I mean? But since I found out what autism really is, I have faced the challenges much better.

It is a challenge, a big one. I always have to find new strategies... trying to understand what is going on is the big challenge.

According to the speeches, the autism acceptance and the delivery of a specific care are a daily challenge faced by parents. In fact, they had experienced anguish and hopelessness stages and some of them had even tried to find miraculous solutions.

The development of an autistic child requires a lot of engagement from parents in dealing with the autism, accepting and understanding the situation, and searching for new approaches linked to family resilience:

...autism was an open door that showed me a new different world I wasn't used to

It is a big learning process, am I right? It's a great learning for life. Every single day is an obstacle that has to be overcome

It was identified in the parents with different religions a strong attachment to God, and this connection enhanced autism acceptance and lack of anxiety:

It is a gift from God. You can write it down.

I have no words... My autistic child... God sent him to me... and I will love him until God takes him back from me.
The birth of an autistic child requires a readjustment of expectations, plans and experiences in order to better face negative feelings, which appears when a child needs more attention and care. [20].

Therefore, it is essential that the acceptance process begins in a family environment in a way that is possible to understand challenges, and identify the potential of the autistic children. As a result of the implementation of that approach, the family and the autistic children's quality of life will be improved.

\section{Conclusion}

The care required by autistic children does not necessarily match with what family member had expected. Consequently, it is necessary to understand their doubts for the establishment of measures that are beyond physical abilities.

In order to improve independence, family members must find new abilities and strategies to stimulate their children to overcome limitations and personal expectative.

The parents pointed out that the medical conditions of autism directly impact parents and caregivers' perception about the disorder. Therefore, it is recommended the creation of specific health strategies for each child that triggers early stimulation and improves social interaction and the development of abilities required for the performance of activities of daily living. Moreover, these specific health strategies increase the children and caregivers' quality of life.

\section{References}

1. Fernandes FD. Famílias com crianças autistas na literatura internacional. Rev Soc. Bras. Fonoaudiologia 2009; 14(3): 427-32. Disponível em: http://www.scielo.br/pdf/rsbf/v14n3/ v14n3a22

2. Fernandes FDM. Pragmática. In: Andrade CRF, Befi-Lopes DM, Fernandes FDM, Wertzner HF. Teste de linguagem infantil nas áreas de fonologia, vocabuilário, fluência e pragmática. Carapicuiba. Pró-Fono; 2004. (cap 4). p. 90. 
3. Stelzer, FG. Uma pequena história do autismo. Cadernos Pandorga de Autismo, vol. 1, 2010. Associação Mantenedora Pandorga. São Leolpodo, RS. Disponível em: http://www. pandorgaautismo.org/includes/downloads/publicacoes/ Pandorga-Caderno1.pdf

4. http:// www.cdc.gov/spanish/especialesCDC/AutismoDatos/

5. Brasil. Ministério da Saúde. Secretaria de Atenção à Saúde. Política Nacional de Saúde da Pessoa Portadora de Deficiência/ Ministério da Saúde, Secretaria de Atenção à Saúde - Brasília: Editora do Ministério da Saúde, 2010. Disponível em: http:// bvsms.saude.gov.br/bvs/publicacoes/politica nacional pessoa com deficiencia.pdf

6. Rabello S, Visani P. Considerações sobre o diagnóstico precoce na clínica do autismo e das psicoses infantis. Rev. Latinoam. Psicopatol. Fundam. [online]. 2012, vol.15, n.2, pp. 293-308. Disponível em: http://www.redalyc.org/ pdf/2330/233022805006.pdf

7. Delfino MRR, Karnopp ZMP, Rosa MRQP, Pasin RR. Repercussões do processo de ensinar-aprender em serviços de saúde na qualidade de vida dos usuários. Trab. Educ. Saúde. 2012 Jul/ Out, v.10, p. 315-333. Disponível em: http://www.scielo.br/pdf/ tes/v10n2/08.pdf

8. Smeha LN, Cezar PK. A vivência da maternidade de mães de crianças com autismo. Psicologia em Estudo. 2011, mar, vol. 16, n.1. Disponível em: http://www.scielo.br/pdf/pe/v16n1/ a06v16n1.pdf

9. Vieira, CMB; Fernandes, FDM. Qualidade de vida em Irmãos de Crianças incluídas no espectro do autismo. CoDAS. 2013; 25(2): 120-27. Disponível em: http://www.scielo.br/pdf/codas/v25n2/ a06v25n2.pdf

10. Nogueira MAA, Martins do Rio SCM. A família com criança autista: apoio de enfermagem. Revista Portuguesa de Enfermagem de Saúde Mental. 2011, n. 5 (Jun). Disponível em: http://www.scielo.mec.pt/pdf/rpesm/n5/n5a03.pdf

11. Cullun N, Ciliska D, Haynes RB, Marks S. Enfermagem baseada em evidências: uma introdução. - Porto Alegre: Artmed, 2010.

12. Minayo, $M C$ de $S$ (org). Pesquisa social: teoria, método e criatividade. - 31ª ed., Petrópolis, Rio de Janeiro: Vozes, 2012.

13. Assunção FBJr., Kuczynski E. Qualidade de Vida na infância e na adolescência: orientação para pediatras e profissionais da saúde mental. Porto Alegre: Artmed, 2009.

14. Marques MH, Dixe MAR. Crianças e jovens autistas: impacto na dinâmica familiar e pessoal de seus pais. Rev. psiquiatr. clín. 2011. Vol.38, n.2. Disponível em: http://www.scielo.br/pdf/rpc/ v38n2/v38n2a05.pdf

15. Smeha, LN; Cezar PK. A vivência da maternidade de mães de crianças com autismo. Psicologia em Estudo. 2011, v.6, n.1, p. 43-50. Disponível em: http://www.scielo.br/pdf/pe/v16n1/ a06v16n1.pdf
16. Ribeiro, SHB. O impacto do autismo na família. Revista Autismo Abril. 2011. Disponível em: http://www.revistaautismo.com.br/ edic-o-1/o-impacto-do-autismo-na-familia

17. Rodrigues JMC, Spencer E. A criança autista: um estudo psicopedagógico. Rio de Janeiro: Wak Editora; 2010

18. Ramos CD. Como fazer o desfralde de autismo. Revista autismo informação gerando ação. 2010. Disponível em: http://dietasgsc. blogspot.com.br/2010/08/revista-autismo-realizacao-de-umsonho.html

19. Cunha, E. Autismo e Inclusão: psicopedagogia e práticas educativas na escola e na família. $2^{a}$ Ed. Rio de Janeiro: Wak Editora; 2010.

20. Serra, D. Autismo, família e inclusão. Polêmica. 2010, v. 9, n. 1, p. 40-56, jan./mar. Disponível em: file:///C:/Users/wmartins/ Downloads/2693-10294-1-PB.pdf

\section{Publish in International Archives of Medicine}

International Archives of Medicine is an open access journal publishing articles encompassing all aspects of medical science and clinical practice. IAM is considered a megajournal with independent sections on all areas of medicine. IAM is a really international journal with authors and board members from all around the world. The journal is widely indexed and classified Q1 in category Medicine. 